\title{
Early Treatment with Reverse Transcriptase Inhibitors Significantly suppresses Peak Plasma IFNa in vivo During Acute Simian Immunodeficiency Virus Infection
}

\author{
Jeffy George ${ }^{1}$, Lynnsey Renn ${ }^{2}$, Daniela Verthely ${ }^{3}$, Mario Roederer ${ }^{4}$, Ronald L. Rabin ${ }^{2}$ \& \\ Joseph J. Mattapallil ${ }^{1 *}$ \\ ${ }^{1}$ Uniformed Services University of the Health Sciences, Bethesda, MD 20814; ${ }^{2} \mathrm{CBER}$, \\ FDA, Silver Spring, MD; ${ }^{2} \mathrm{CDER}$, FDA, Silver Spring, MD; ${ }^{4} \mathrm{VRC}, \mathrm{NIH}$, Bethesda, MD.
}

Key words: HIV, SIV, IFN $\alpha$, IFN $\beta$, Subtypes, Dendritic cells, Mucosa 
42 insights into the kinetics of innate interferon responses during early stages of infection,

43 and provide evidence that DC's are a major in vivo source of innate IFN during acute

44 SIV infection.

\section{Abstract:}

Innate interferons (IFN) are comprised of multiple Type I and III subtypes. The in vivo kinetics of subtype responses during human immunodeficiency virus (HIV) infection is not well defined. Using the acute simian immunodeficiency virus (SIV) infection model, we show that plasma IFNa levels peak at day 10 post-infection (pi) after which they rapidly declined. The mRNA expression of Type I and III IFN subtypes were significantly elevated in the lymph nodes (LN) at day 10 pi. Though the expression levels of all subtypes declined by day $14-31$ pi, numerous subtypes remained elevated suggesting that ongoing viral replication in $\mathrm{LN}$ continues to drive induction of these subtypes. Interestingly, treatment with reverse transcriptase (RT) inhibitors at day $7 \mathrm{pi}$ significantly suppressed plasma IFNa responses by day 10 pi that significantly correlated with cell-associated SIV DNA loads suggesting that RT byproducts such as viral DNA likely plays a role in driving IFN responses during acute SIV infection.

Quantification of Type I and III subtype transcripts in sorted subsets of LN CD4+ and CD8+ T cells, CD14+/CD14- monocytes/macrophages, and total CD11c/CD123+ dendritic cells (DC) at day 10 pi showed that DC expressed $\sim 3-4$ log more subtype transcripts as compared to the other subsets. Taken together, our results provide new 


\section{Introduction}

Human and simian immunodeficiency virus (HIV and SIV) infections are

characterized by significant acute pathogenesis that is accompanied by massive viral replication, systemic loss of CD4 memory T cells, acute immune activation, and innate immune responses.

Innate interferons (IFN) are anti-viral cytokines that are released during viral

52 infections in response to the stimulation of various pathogen recognition receptors

53 (PRR) such as Toll-like receptors (TLR), RIG-I, MDA-5 etc. IFN exert their anti-viral

54 action either by inducing the expression of interferon-stimulated genes (ISG) that

55 directly suppresses viral replication or by modulating innate and adaptive immune responses[1;2; 3; 4]. Numerous studies have shown that IFNa potently inhibits HIV by

57 inhibiting reverse transcription and viral expression from integrated provirus, HIV

58 replication in primary monocyte-derived macrophages, and virion release from infected

59 cell lines $[5 ; 6 ; 7 ; 8 ; 9 ; 10]$. IFN- $\alpha$ treatment of HIV-1 infected cells suppressed viral

60 replication[11;12;13;14;15;16]. Others have shown that acute SIV infection is

61 characterized by the release of IFN and upregulation of ISG[17;18;19;20], whereas

62 IFN- $\alpha$ treatment of HIV-1 infected cells suppressed viral replication during early stages

63 of replication[11;12;13;14;15;16]. Blocking of IFN signaling with antibodies to IFNR1

64 was shown to increase viremia whereas treatment with IFN- $\alpha 2$ increased the expression

65 of ISG[21] in SIV infected macaques suggesting a protective role for IFN responses in 66 controlling viral infection.

67 Innate IFN include two multi-gene families that code for numerous Type I and III IFN 68 subtypes. Type I IFN gene family includes IFN $\beta$, IFN $\omega$ and multiple subtypes of IFN- $\alpha 1$, 
$-\alpha 2,-\alpha 4,-\alpha 5,-\alpha 6,-\alpha 7,-\alpha 8,-\alpha 10,-\alpha 13,-\alpha 14,-\alpha 16,-\alpha 17$ and $-\alpha 21$ subtypes in

70 humans[22], and IFNa-01/13, 02, 06, 08, 14, 16, 23, 24, 25, 26, 27, 28, 29 in rhesus

71 macaques[23]. Both humans and macaques express the type III IFN gene family that

72 encodes for IFN $\lambda$-1, IFN $\lambda$-2, IFN $\lambda$-3 subtypes[22; 23]. Recent studies have identified

73 IFN- $\lambda 4$ as a new Type III subtype in humans[24] with antiviral activity[25].

All Type I IFN subtypes signal through a common cell-surface receptor that is composed of INFAR-1 and INFAR-2, whereas Type III IFN signals through a receptor complex consisting of the IL-28R and IL-10R $326 ; 27 ; 28]$.

Interestingly, however, different subtypes have been shown to display different binding affinities for their receptors[29;30;31] that in turn was shown to influence their action and potency. Some subtypes such as IFNa-10 has been shown to bind the IFNAR1/2 receptor at $10-100$ fold greater affinity that IFNa-01[32]. IFNa-10 was found to be highly effective against Semliki forest virus (SFV) and Vesicular stomatitis virus (VSV) whereas IFNa-02 was the least effective among the 9 different subtypes tested[33; 34]. On the other hand, IFNa-02 binding was found to induce chemotaxis genes and shown to be most effective against HIV-1[35] whereas IFNa-08 induced ISG's that protected against HCV replication[36]. Other studies have reported that there were significant differences in the in vitro anti-viral and anti-proliferative effects between subtypes[33; 37; 38; 39; 40], with variable effect on T cells and dendritic cells (DC), and B cell proliferation[41; 42]. These studies raise the prospect that various subtypes may play a differential role in acute HIV infection. Harper et al[43] examined the expression of different IFN $\alpha$ subtypes in HIV-1 exposed plasmacytoid dendritic cells (pDC), and determined the 
92 potency of each IFN $\alpha$ subtype ex vivo using the Lamina propria aggregate culture

93 model. They reported that IFN subtypes were highly expressed in pDC after exposure to

94 HIV-1, and the relative potencies of subtypes was influenced by their binding affinities to

95 the Type I IFNR with IFN $\alpha 8$ and IFN $\alpha 14$ being most potent at inhibiting HIV infectivity.

96 Zaritsky et al[44] examined the expression of both total IFNa mRNA and the pattern of

97 IFNa subtype mRNA expression in pigtailed macques (PTM) between day 7 and 21 pi

98 and reported that expression and pattern of subtypes expressed differed between the

99 brain, lung and spleen. There is limited information regarding the in vivo expression of

100 various Type I and III subtypes in the lymph nodes, jejunal mucosa and PBMC and the

101 source of the various Type I and III subtypes during the early acute stages of HIV

102 infection.

103 We sought to address this question using the SIV infected rhesus macaque model

104 and examined the kinetics of IFN $\alpha$ levels in the plasma during the $1^{\text {st }}$ two weeks of

105 infection and compared them to animals that were treated with reverser transcriptase

106 (RT) inhibitors very early during the course of infection. To determine if acute SIV

107 infection was characterized by differences in the expression of various subtypes, we

108 examined the mRNA expression profile of both Type I and Type III IFN subtypes in

109 peripheral blood mononuclear cells (PBMC), jejunal mucosa and lymph nodes (LN)

110 during early stages of SIV infection using a quantitative RT-PCR assay. Our results

111 showed that plasma IFN $\alpha$ levels were significantly elevated at day 10- post infection (pi)

112 in untreated animals but was significantly suppressed in treated animals when ART was

113 initiated at day 7 pi. Plasma IFN $\alpha$ levels significantly correlated with CD4 T cell

114 associated SIV DNA loads suggesting a role of viral DNA in the induction of IFN $\alpha$. Both 
115 Type I and III IFN subtypes were differentially expressed during acute SIV infection with

116 most subtypes being significantly elevated in the LN as compared to the mucosa and

117 peripheral blood. Analysis of various cellular sources in the LN at day 10 pi showed that

118 dendritic cells were the primary in vivo source of all IFN subtypes as compared to other

119 cellular subsets.

120 Materials and Methods

121 Animals, infection and samples

122 Archived cryopreserved cells from peripheral blood (PBMC; uninfected $n=10$;

123 day 10 pi $n=10$; day 14 - 31 pi $n=8)$, lymph nodes $(L N$; uninfected $n=5$; day 10 pi $n=$

124 8; day 14 - 31 pi $n=9$ ) and jejunum (uninfected $n=5$; day 10 PI $n=8$; day 14 - 31 pi $n$

$125=5$ ) that were collected from healthy and SIVmac251 infected rhesus macaques

126 (Macaca mulatta) of Indian origin were used in this cross-sectional study. Additionally,

127 archived cells and plasma from rhesus macaques that were treated with a combination

128 of RT inhibitors PMPA (Tenofovir) and FTC (Emtricitabine) were used for analysis;

129 PMPA and FTC were administered at 20-30 mg / Kg BW / day starting at day 7 pi. The

130 animals were housed in accordance with the American Association for Accreditation of

131 Laboratory Animal guidelines and were seronegative for SIV, simian retrovirus (SRV)

132 and simian T-cell leukemia virus (STLV) type-1 prior to SIV challenge.

133 PBMC was isolated by density gradient centrifugation and cells from LN were

134 isolated by mechanical disruption. Cells from the jejunal mucosa were isolated by

135 enzymatic digestion and percoll gradient centrifugation as per procedures described

136 previously[45; 46; 47; 48; 49; 50].

137 Plasma viral loads were determined by real-time PCR using reverse-transcribed 
138 viral RNA as the template, as previously described [51]. CD4 T cell associated viral

139 loads were determined in sorted memory CD4 T cell subsets using a highly quantitative

140 PCR assay for SIV-gag as described previously[52]. The level of IFN $\alpha$ in plasma was

141 determined using a human IFNa pan ELISA kit as per manufacturers instructions (limit

142 of detection: $4 \mathrm{pg} / \mathrm{ml})$.

\section{Antibodies and flow cytometry}

144 Cryopreserved cells were labeled with a panel of CD3-Cy-7APC, CD4-APC,

145 CD8-Alexa700, CD95-FITC and CD28-Cy-5PE (BD Biosciences) and memory CD4 T

146 cells were sorted using a Becton Dickinson Aria sorter and used for determining CD4 T

147 cell-associated viral loads. Memory CD4 T cells was discriminated based on the

148 expression of CD28 and CD95 as described previously[52; 53]. All the antibodies were

149 titrated using rhesus macaque PBMC.

150 To determine the expression of IFN subtypes in cell subsets, live LN cells at day

15110 pi were stained with Vivid live dead marker and anti-CD3-Cy-7APC, CD4-BV605,

152 CD8-Alexa700, CD14-FITC, CD11c-APC and CD123-PE, and CD3+CD4+ T cells

153 (CD4), CD3+CD8+ T cells (CD8), total CD3-CD11C-CD123-CD14+/CD14- monocytes/

154 macrophages (CD14+/CD14-) and CD3-CD14-CD11C+CD123+ dendritic cells (DC)

155 were sorted using BD Aria sorter. Dead cells were excluded and live cell subsets that

156 were sufficient to yield a minimum of $\sim 500 \mathrm{ng}$ of RNA were sorted for each subset

157 (>98\% purity) and used for RNA extraction. The number of cells required to yield $\sim 500$

$158 \mathrm{ng}$ of RNA was determined in a cell titration experiment.

159 Absolute quantification of Macaca mulatta IFN subtype mRNA levels by qRT-PCR 
RNA was extracted from whole cell populations (total PBMC, LN and jejunum cells), and sorted cell subsets (CD4, CD8, monocytes, macrophages, and DC) using the

162 RNeasy Mini Kit (Qiagen, Valencia, CA, USA) and treated with RNase-free DNase

163 (Qiagen). Total RNA was quantified using a Nanodrop spectrophotometer and $500 \mathrm{ng}$ of

164 RNA was reverse transcribed with the Verso cDNA Synthesis Kit (Thermo Scientific,

165 Rockford, IL, USA) using a mixture of random hexamers and anchored oligo dT primers.

166 The run conditions were as follows: $42^{\circ} \mathrm{C}$ for $30 \mathrm{~min}, 95^{\circ} \mathrm{C}$ for $2 \mathrm{~min}, 4^{\circ} \mathrm{C}$ for $\infty$. Samples

167 were subsequently treated with RNase H (New England Biolabs, Ipswich, MA, USA)

168 following the manufacturer's instructions.

169 The copy numbers of type I and III IFN was determined by qRT-PCR as 170 previously described[23; 54]. Briefly, Macaca mulatta type I and III interferon subtype

171 (IFNa-01/13, 02, 06, 08, 14, 16, 23, 24, 25, 26, 27, 28, 29, IFN $\beta$, IFN $\omega$, IFN $\lambda-1$ and

172 IFN $\lambda$-3) specific primers and probes[23] were distributed into 384-well assay plates with

173 the Solo automated multi-channel pipettor (Hudson Robotics, Inc., Springfield, NJ),

174 dried, and stored in the dark at $4^{\circ} \mathrm{C}$ until use. TaqMan Fast Universal PCR Master Mix

175 and the primer/probe sets for GAPDH and $18 S$ were purchased from Applied

176 Biosystems (Foster City, CA, USA). Primers for the IFN transcripts and Molecular

177 Beacon probes were synthesized by the Facility for Biotechnology Resources at the

178 Center for Biologics Evaluation and Research (Silver Spring, MD, USA). LNA probes

179 were synthesized by Sigma-Aldrich (Saint Louis, MO, USA). All primer and probe stocks

180 were purified by high-performance liquid chromatography. The master mix/water

181 mixtures, sample cDNA, housekeeping gene primer/probe sets, and standards were

182 added to each well using electronic multichannel pipettes (Thermo-Fisher Scientific, 
183 Waltham, MA, USA). No template controls (NTC) and four point standard curves of

184 linearized plasmids containing the IFN sequences as inserts were included on each

185 assay plate. The total volume of each PCR reaction per well was $7.5 \mu \mathrm{l}(3.75 \mu \mathrm{l}$ PCR

186 Master Mix, $2.25 \mu \mathrm{l}$ primer/probe sets and $1.5 \mu \mathrm{l}$ cDNA template). Sealed plates were

187 centrifuged at $1500 \mathrm{rpm}$, mixed with a MixMate two-dimensional plate vortexer at 2600

188 rpm (Eppendorf, Westbury, NY, USA), and centrifuged again. After centrifugation, the

189 qRT-PCR assay plates were run on the ViiA 7 Real-Time PCR System (Life

190 Technologies, Grand Island, NY, USA) using the following run conditions: $50^{\circ} \mathrm{C}$ for 2

$191 \mathrm{~min}, 95^{\circ} \mathrm{C}$ for $10 \mathrm{~min}, 40$ cycles of $95^{\circ} \mathrm{C}$ for $15 \mathrm{sec}, 60^{\circ} \mathrm{C}$ for $1 \mathrm{~min}$. Data was analyzed

192 using the ViiA 7 RUO Software (Life Technologies) and exported into a Microsoft Excel

193 Spreadsheet designed for in-house analysis. Each four point standard curve set was

194 graphed and analyzed for linearity. Absolute copy numbers of each IFN transcript were

195 calculated based on the four point standard curve and target gene transcripts were

196 normalized to micrograms of RNA input per well.

197 Data analysis

$198 \quad$ Flow cytometric data was analyzed using FlowJo version 9.2 (Tree Star, Inc.,

199 Ashland, OR). Statistical analysis was performed using GraphPad Prism Version 5.0

200 software (GraphPad Prism Software, Inc. San Diego, CA). Mann Whitney U test was

201 used to determine significance and spearman's rank was used to determine

202 correlations. A $p<0.05$ was considered significant. Error bars represent standard error.

\section{Results}

204 Kinetics of plasma IFNa levels correlate with viral infection 
Previous studies[19; 55] have shown that acute SIV infection was characterized

206

207

208

209

210

211

212

213

214

215

216

217

218

219

220

221

222

223

224 225 untreated animals.

226

227

by an increase in plasma IFNa levels. To confirm these findings, we examined the levels of IFNa in plasma collected prior to infection, and at day 7, 10 and $14 \mathrm{pi}$ and correlated them with plasma viral loads. Our results showed that plasma viremia increased after infection and peaked at day $10 \mathrm{pi}$ and continued to remain high at day 14 pi (Fig. 1a). As reported previously[19; 55; 56; 57], plasma IFNa levels were found to peak at day 10 pi that was followed by a significant decline to near baseline levels by day $14 \mathrm{pi}$ (Fig. 1b). Interestingly, plasma viral loads $(r=0.4949 ; p=0.0521)$ at day $10 \mathrm{pi}$ did not significantly correlate with plasma IFNa levels at day 10 pi (Fig. 1c).

Reverse transcriptase inhibitors administered at day 7 pi significantly suppresses plasma IFNa levels and CD4 T cell associated SIV-DNA loads at day $10 \mathrm{pi}$

Studies[58; 59] have shown that endosomal Toll-like-receptors (TLR) such as

TLR-7, 8, and 9 play a key role in induction of IFNa. However, in vivo administration of

TLR-7 and 9 antagonists had little or no effect on plasma IFN $\alpha$ levels[19] suggesting to a role for other mechanisms in this process. On the other hand, recent studies[60] have shown that a cytoplasmic DNA sensor, cGAS plays a role in induction of IFN $\alpha$ responses in macrophages raising the possibility that similar mechanisms may be driving early IFNa responses during SIV infection. To address this question we examined plasma IFNa levels in rhesus macaques that initiated anti-retroviral therapy with reverse transcriptase (RT) inhibitors at day $7 \mathrm{pi}$ and compared them SIV infected

Our results show that initiation of therapy early during infection was associated with a significant decrease in peak plasma and cell-associated SIV DNA as compared 
228 to untreated animals (Fig. 1a and 1d). Suppression of infection was accompanied by a

229 significant decline in plasma IFNa levels to near baseline levels (Fig. 1b). Though

230 plasma viremia remained high in treated animals plasma IFN $\alpha$ levels remained at near

231 baseline levels in treated animals at day 10 and 14 pi. These findings along with the

232 lack of a significant correlation between plasma viral loads and plasma IFN $\alpha$ levels at

233 day 10 pi suggest that byproducts of reverse transcription such as viral DNA maybe

234 playing a key role in driving IFNa responses very early during SIV infection. In line with

235 this argument, we found a significantly high positive correlation between cell-associated

236 SIV DNA loads and plasma IFNa levels $(r=0.7762, p=0.0022)$ at day 10 pi (Fig. 1e).

237 IFN subtypes are differentially expressed in PBMC, LN and Jejunal mucosa

238 SIV has been shown to extensively replicate in the $L N$ and mucosa during acute 239 stages of infection $[52 ; 61 ; 62 ; 63 ; 64]$. We hypothesized that these tissues were a likely

240 source for the significant increase in IFN levels during the acute SIV infection. As IFN

241 harbors numerous subtypes, we quantified the copy numbers of both Type I and III IFN

242 subtype mRNA in total cells isolated from the PBMC, LN and jejunal mucosa at day 10,

$24314-31$ pi and compared them to pre-infection levels (Fig. 2).

244 Our results showed that the expression of IFN subtypes was highly restricted in

245 PBMC with only IFNa-01/13 and IFN $\lambda$-1 being significantly upregulated at day 10 pi as

246 compared to uninfected animals. Interestingly, IFNa-14 and 16 levels significantly

247 declined by day 10 pi as compared to pre-infection levels. Like PBMC, cells from the

248 jejunal mucosa at day 10 pi were found to selectively upregulate IFNa-01/13, 06, 08, 23,

249 IFN $\omega$ and IFN $\lambda-1$ subtypes as compared to preinfection values. Expression levels in 250 both PBMC and jejunal mucosa declined significantly by day $14-31$ pi with the loss 
251 being more pronounced in the jejunal mucosa that likely coincided with the massive loss

252 of cells reported to occur at these sites during acute stages of infection.

253 Unlike PBMC and jejunal mucosa, however, the expression levels of all the Type

254 I and III subtypes except for IFN $\alpha-26$ were significantly upregulated at day 10 pi in the

255 LN as compared to uninfected animals. The levels of IFN expression in LN were

256 significantly higher in magnitude than both PBMC and jejunal mucosa suggesting that

257 LN were a significant source of early IFN response. Though peak expression levels

258 declined by day $14-31$ as compared to day 10 pi, the expression levels of IFNa-01/13,

$25908,23,24,25,28,29$, IFN $\beta$ and IFN $\lambda-1$ remained significantly higher than preinfection

260 levels suggesting that ongoing viral replication continues to drive innate IFN responses

261 in organized lymphoid tissues after viral replication had peaked. IFN $\lambda$-3 was

262 undetectable in all the three tissues we examined.

263 Dendritic cells are the primary producers of both Type I and III IFN during acute

264 SIV infection

265 Our results showed that LN expressed $\sim 3-4$ logs more Type I and III IFN

266 subtype mRNA transcripts at day 10 pi as compared other tissues. To determine the

267 cellular source of the different subtypes, we sorted highly purified subsets of CD4 and

268 CD8 T cells, total monocytes/macrophages (CD14+/CD14-) and total DC's (CD11C+

269 and $\mathrm{CD123+)}$ from the $\mathrm{LN}$ at day 10 pi and quantified the expression of IFN subtypes in

270 these subsets (Fig. 3). We were unable to obtain sufficient LN samples prior to infection

271 for sorting cell subsets, hence restricted our analysis to samples collected at day $10 \mathrm{pi}$.

272 Additionally, given the limited amount of samples we had and the low frequency of both

273 CD11C+ myeloid DC and CD123+ plasmacytoid DC, we decided to sort total DC instead 
274 of individual subsets to extract sufficient RNA needed for qRT-PCR analysis of various

275 IFN subtypes. A similar rationale was used to sort total monocyte/macrophage subsets.

276 Our results showed that except for IFNa-26, at peak of infection DC subsets expressed

277 significantly higher numbers of all IFN subtypes in vivo as compared to the other cell

278 subsets. There was no significant difference between the other four subsets we

279 examined.

280 Discussion

HIV-1 and SIV infections are characterized by a significant innate immune 282 response early in infection[65]. Others have reported upregulated expression of

283 interferon stimulating genes (ISG) that have been associated with control of

284 infection[65]. The mechanisms that drive early IFN response have been a matter of

285 intense investigation over a number of years though the exact cause for induction of

286 Type I, and III IFN response in vivo remains unclear. Our results suggest that RT

287 byproducts such as viral DNA may play a key role in this process; initiation of anti-

288 retroviral therapy with RT inhibitors at day 7 pi significantly suppressed plasma IFN $\alpha$

289 levels to that of baseline by day $10 \mathrm{pi}$ as compared to $\sim 3000 \mathrm{pg} / \mathrm{ml}$ of IFN $\alpha$ at day $10 \mathrm{pi}$

290 in SIV infected untreated animals. Interestingly, the plasma viral loads remained high

291 ( 6 logs) in treated animals at day 10 pi suggesting that endosomal

292 compartmentalization of virus may not be the key driver of early IFN responses.

293 Otherwise, we should have seen higher levels of plasma IFN $\alpha$ as viral RNA levels

294 remained significantly high in the plasma from treated animals. In line with this

295 argument, studies[19] have shown that treatment of SIV infected rhesus macaques with 
296 TLR7 and TLR9 antagonists had little or no effect on peak plasma IFN $\alpha$ levels during 297 the first two weeks of SIV infection.

298 On the other hand, suppression of IFN responses by RT inhibitors suggests that 299 RT byproducts such as the reverse transcribed viral DNA might be driving early IFN 300 responses during acute SIV infection. Recent studies have demonstrated a key role of 301 the cytoplasmic DNA sensor cGAS in macrophages infected with HIV and SIV[60]. 302 Lahaye et al[66] showed that host sensing of HIV-2, a virus that is more similar to SIV, 303 required viral cDNA synthesis rather than nuclear entry or genome integration, and this 304 sensing in DC's were mediated by cGAS. Martin-Gayo et al[67] showed that 305 conventional DC from HIV infected elite controllers produce high levels of innate IFN 306 that was associated with an accumulation of viral reverse transcripts and blocking of 307 cGAS or reverse transcription inhibited these responses. Herzner et al[68] showed that 308 single stranded HIV-1 DNA activates cGAS and HIV-1 reverse transcripts were the 309 predominant viral DNA species in the cytoplasm of macrophages during early infection.

310 The above studies along with our results suggest that reverse transcribed viral DNA and 311 cytoplasmic sensors likely play an important role in the induction of innate IFN

312 responses in vivo during acute SIV infection.

313 That innate IFN response in plasma peaks very early during infection has been

314 known for some time. Previous studies[19; 55] have shown that plasma IFNa levels 315 peak between days 7 - 10 pi in SIV infected animals after which they rapidly decline to 316 baseline levels. Our findings were in line with these earlier reports. What is, however, 317 not clear is the kinetics of the various IFN subtype responses in vivo during acute 318 stages of SIV infection, and if these responses differ between tissues. Our results 
319 showed that various subtypes were differentially expressed in mucosal and peripheral

320 tissues with nearly all of the detectable subtypes being expressed at significantly high

321 levels in the LN as compared to PBMC and jejunum; at day 10 pi only IFNa-01/13 and

322 IFN $\lambda$-1 transcripts were significantly upregulated in PBMC, whereas IFNa-01/13, 06, 08,

32323 , IFN $\omega$ and IFN $\lambda-1$ subtypes were significantly upregulated in the jejunal mucosa.

324 IFN $\alpha-26$ and IFN $\lambda-3$ were undetectable in all the tissues we examined. The expression

325 levels in both PBMC and jejunal mucosa significantly declined by day $14-31$ pi.

326 Interestingly, there was a significant decline in IFNa-14 and 16 subtypes in PBMC by

327 day 10 pi. Harper et al[43] using an ex vivo model of HIV infection showed that IFNa-06,

32808 and 14 were the most potent of subtypes examined that showed significant HIV

329 restriction in the mucosa. On the other hand, IFNa-01 and 02 had the weakest antiviral

330 activity suggesting that decline of these highly restrictive subtypes may contribute to the

331 increased pathogenesis and replication in the gut mucosa[43]. Likewise, Lavender et

332 al[69] showed that IFN $\alpha-14$ had significantly higher antiviral activity against HIV

333 infection in humanized mouse models as compared to other subtypes.

334 In contrast to both PBMC and jejunal mucosa, the expression and magnitude of

335 most subtypes were significantly upregulated in the $L N$ at day 10 pi suggesting that $L N$

336 was a significant source of early IFN response during acute SIV infection. Unlike the

337 PBMC and jejunum, however, the expression levels of IFNa-01/13, 08, 23, 24, 25, 28,

33829 , IFN $\beta$ and IFN $\lambda-1$ transcripts remained significantly higher at day $14-31$ pi as

339 compared to pre-infection levels suggesting that ongoing replication continues to drive

340 specific IFN subtype responses in the LN. The exact reason why only a subset of IFN

341 subtypes were expressed is difficult to determine at this point. Previous studies[44] 
342 examined the relative expression of IFNa subtypes in SIV infected PTM during the $1^{\text {st }} 3$

343 weeks of infection and found tissue specific differences in the expression pattern of

344 various IFNa subtypes; only subtypes 2, 6, and 13 were expressed in the brain of SIV

345 infected PTM at day 7 pi, whereas only subtypes 6 and 13 were upregulated in the lung.

346 In contrast to the brain and lung, all the 13 subtypes were expressed in the spleen with

347 subtypes 2,8 , and 13 being the most abundantly expressed at day 7 pi whereas

348 subtypes 4, 17 and 21 were least abundantly expressed.

349 It is unlikely that the lower levels of IFN subtypes expressed in the jejunum as

350 compared to the LN was due to the lower frequency of IFN producing cells at these

351 sites as fewer cells are likely to lower the magnitude of expression rather than the

352 pattern of expression of IFN subtypes. It is, however, difficult to rule this out. The loss of

353 DC subsets from peripheral blood may explain the decline in expression of subtypes in

354 blood as numerous studies have documented that both DC and macrophages migrate

355 to the gut mucosa during SIV infection[56; 70; 71; 72; 73; 74; 75]. The simultaneous

356 decline in IFN expression in both mucosal and peripheral tissues, however, raises the

357 possibility that $\mathrm{DC}$ are either lost or become refractive in both PBMC and the mucosa at

358 the same time. Wonderlich et al[57] reported that macrophages and myeloid DC

359 subsets loose stimulating function and was associated with decreased IFNa production

360 during SIV infection.

361 Compared to PBMC and jejunum, LN is enriched for IFN producing cells such as

362 DC that might explain the significantly higher levels of all IFN subtypes in the LN. In fact,

363 we observed significantly higher levels of all detectable IFN subtypes in the DC's from

364 the LN as compared to other cell subsets; DC's had $\sim 100,000$ fold more copies of IFN 
365 subtype transcripts than either T cells or monocyte/macrophage subsets. Our results for

366 the first time provide in vivo evidence for previously reported in vitro studies[76; 77; 78;

$36779 ; 80]$ showing that DC produce significantly higher amounts of IFN that other cell

368 types.

Previous studies have reported that LN DC's were major producers of Type I

370 IFNa during acute SIV infection[55; 81; 82] whereas others have shown that pDC's were

371 actively recruited from circulation into the LN during SIV infection[71; 83]. Bruel et al[55]

372 showed that pDC were the major producers of IFN $\alpha$ in the gut and lymphoid tissues

373 during acute SIV infection. Interestingly, there was no difference in the IFN transcript

374 levels between CD4+ T cells and other non-DC subsets we examined even though CD4

375 T cells are highly infected at day 10 pi (Fig. 1d). There is little or no evidence in the

376 literature showing that CD4 T cells were capable of making innate IFN responses during

377 viral infection though they have been shown to upregulate the expression of ISG during

378 acute stages of SIV infection. Like CD4 T cells, it was somewhat surprising that we did

379 not see any significant upregulation of IFN transcripts monocytes/macrophage subsets

380 even though previous studies have shown that macrophages carry SIV DNA[84]. The

381 exact reason why macrophages did not express IFN in vivo very early in infection has to

382 be examined further and additional studies are needed to clarify these questions in

383 detail. It is difficult to determine from our studies if cellular subsets other than DC's in

384 the LN upregulated the expression of IFN subtypes at day 10 pi as we did not have

385 sufficient cells from healthy $L N$ to compare. However, there is little or no evidence of

386 CD8 T cells producing IFNa during SIV infection and transcript levels in CD8 T cells did

387 not differ from the other non-DC subsets suggesting that cell subsets other than DC's 
388 likely did not upregulate the expression of innate IFN. Future studies will examine this 389 question in greater detail.

390 In conclusion, our studies provide new insights into the kinetics of different Type I

391 and III IFN subtypes during acute SIV infection and identifies DC's as a major in vivo

392 cellular source of IFN subtypes. The significant suppression of plasma IFN $\alpha$ with RT

393 inhibitors suggest that viral DNA and cytoplasmic DNA sensors likely play a role in

394 driving Type I and III IFN responses during acute SIV infection. 


\section{Acknowledgements}

We thank Olusegun Onabajo, Sean Maynard and Sandra Bixler at the Uniformed

398 Services University for assistance with processing the samples. Kateryna Lund at the

399 Biomedical Instrumentation Center; Matt Collins at Bioqual Inc., Rockville, MD for expert 400 assistance with the animals.

$401 \quad$ The described project was supported by funds (R0731976) from the Uniformed

402 Services University of the Health Sciences to JJM. The opinions or assertions contained

403 herein are the private ones of the authors and are not to be construed as official or

404 reflecting the views of the Department of Defense, the Uniformed Services University of

405 the Health Sciences or any other agency of the U.S. Government.

$406 \quad$ The authors declare no financial conflict of interest.

407

408

409

410

411

412 


\section{References}

[1] G. Dusheiko, Side effects of alpha interferon in chronic hepatitis C. Hepatology 26 (1997) 112S-121S.

[2] Y. Koyama, Y. Tanaka, S. Oda, U. Yamashita, and S. Eto, Antiviral and antiproliferative activities of recombinant human interferon alpha 2, beta and gamma on HTLV-I and ATL cells in vitro. J UOEH 12 (1990) 149-61.

[3] F. Witter, F. Barouki, D. Griffin, P. Nadler, A. Woods, D. Wood, and P. Lietman, Biologic response (antiviral) to recombinant human interferon alpha $2 \mathrm{a}$ as a function of dose and route of administration in healthy volunteers. Clin Pharmacol Ther 42 (1987) 567-75.

[4] H. Zhu, M. Butera, D.R. Nelson, and C. Liu, Novel type I interferon IL-28A suppresses hepatitis C viral RNA replication. Virol J 2 (2005) 80.

[5] C. Lapenta, S.M. Santini, E. Proietti, P. Rizza, M. Logozzi, M. Spada, S. Parlato, S. Fais, P.M. Pitha, and F. Belardelli, Type I interferon is a powerful inhibitor of in vivo HIV-1 infection and preserves human CD4(+) T cells from virus-induced depletion in SCID mice transplanted with human cells. Virology 263 (1999) 7888.

[6] P. Leissner, V. Calenda, M. Marigliano, K. Sanhadji, J.L. Touraine, A. Pavirani, and M. Mehtali, [In vitro and in vivo inhibition of HIV1 replication by retroviral transfer of interferon alpha, beta, or gamma genes: application to gene therapy of AIDS]. Ann Biol Clin (Paris) 56 (1998) 167-73.

[7] G. Poli, P. Biswas, and A.S. Fauci, Interferons in the pathogenesis and treatment of human immunodeficiency virus infection. Antiviral Res 24 (1994) 221-33.

[8] W. Popik, and P.M. Pitha, Exploitation of cellular signaling by HIV-1: unwelcome guests with master keys that signal their entry. Virology 276 (2000) 1-6.

[9] K. Sanhadji, P. Leissner, R. Firouzi, F. Pelloquin, L. Kehrli, M. Marigliano, V. Calenda, M. Ottmann, J.C. Tardy, M. Mehtali, and J.L. Touraine, Experimental gene therapy: the transfer of Tat-inducible interferon genes protects human cells against HIV-1 challenge in vitro and in vivo in severe combined immunodeficient mice. AIDS 11 (1997) 977-86.

[10] M. Weiden, N. Tanaka, Y. Qiao, B.Y. Zhao, Y. Honda, K. Nakata, A. Canova, D.E. Levy, W.N. Rom, and R. Pine, Differentiation of monocytes to macrophages switches the Mycobacterium tuberculosis effect on HIV-1 replication from stimulation to inhibition: modulation of interferon response and CCAAT/enhancer binding protein beta expression. J Immunol 165 (2000) 2028-39.

[11] L. Baca-Regen, N. Heinzinger, M. Stevenson, and H.E. Gendelman, Alpha interferon-induced antiretroviral activities: restriction of viral nucleic acid synthesis and progeny virion production in human immunodeficiency virus type 1-infected monocytes. J Virol 68 (1994) 7559-65.

[12] E.M. Coccia, B. Krust, and A.G. Hovanessian, Specific inhibition of viral protein synthesis in HIV-infected cells in response to interferon treatment. J Biol Chem 269 (1994) 23087-94.

[13] B.F. Fernie, G. Poli, and A.S. Fauci, Alpha interferon suppresses virion but not soluble human immunodeficiency virus antigen production in chronically infected T-lymphocytic cells. J Virol 65 (1991) 3968-71. 
[14] P. Kinzl, T. Otani, R. Benz, and J. Minowada, Interferon-alpha and -gamma differentially reduce rapid immature T-cell death by contact with HIV-1 carrier cell clones in vitro. Microbiol Immunol 41 (1997) 709-16.

[15] P.R. Meylan, J.C. Guatelli, J.R. Munis, D.D. Richman, and R.S. Kornbluth, Mechanisms for the inhibition of HIV replication by interferons-alpha, -beta, and gamma in primary human macrophages. Virology 193 (1993) 138-48.

[16] Y. Shirazi, and P.M. Pitha, Alpha interferon inhibits early stages of the human immunodeficiency virus type 1 replication cycle. J Virol 66 (1992) 1321-8.

[17] K. Abel, M.J. Alegria-Hartman, K. Rothaeusler, M. Marthas, and C.J. Miller, The relationship between simian immunodeficiency virus RNA levels and the mRNA levels of alpha/beta interferons (IFN-alpha/beta) and IFN-alpha/beta-inducible Mx in lymphoid tissues of rhesus macaques during acute and chronic infection. $J$ Virol 76 (2002) 8433-45.

[18] S.E. Bosinger, Q. Li, S.N. Gordon, N.R. Klatt, L. Duan, L. Xu, N. Francella, A. Sidahmed, A.J. Smith, E.M. Cramer, M. Zeng, D. Masopust, J.V. Carlis, L. Ran, T.H. Vanderford, M. Paiardini, R.B. Isett, D.A. Baldwin, J.G. Else, S.I. Staprans, G. Silvestri, A.T. Haase, and D.J. Kelvin, Global genomic analysis reveals rapid control of a robust innate response in SIV-infected sooty mangabeys. J Clin Invest 119 (2009) 3556-72.

[19] M. Kader, A.P. Smith, C. Guiducci, E.R. Wonderlich, D. Normolle, S.C. Watkins, F.J. Barrat, and S.M. Barratt-Boyes, Blocking TLR7- and TLR9-mediated IFNalpha production by plasmacytoid dendritic cells does not diminish immune activation in early SIV infection. PLoS Pathog 9 (2013) e1003530.

[20] T.M. Schaefer, C.L. Fuller, S. Basu, B.A. Fallert, S.L. Poveda, S.K. Sanghavi, Y.K. Choi, D.E. Kirschner, E. Feingold, and T.A. Reinhart, Increased expression of interferon-inducible genes in macaque lung tissues during simian immunodeficiency virus infection. Microbes Infect 8 (2006) 1839-50.

[21] N.G. Sandler, S.E. Bosinger, J.D. Estes, R.T. Zhu, G.K. Tharp, E. Boritz, D. Levin, S. Wijeyesinghe, K.N. Makamdop, G.Q. del Prete, B.J. Hill, J.K. Timmer, E. Reiss, G. Yarden, S. Darko, E. Contijoch, J.P. Todd, G. Silvestri, M. Nason, R.B. Norgren, Jr., B.F. Keele, S. Rao, J.A. Langer, J.D. Lifson, G. Schreiber, and D.C. Douek, Type I interferon responses in rhesus macaques prevent SIV infection and slow disease progression. Nature 511 (2014) 601-5.

[22] R. Szubin, W.L. Chang, T. Greasby, L. Beckett, and N. Baumgarth, Rigid interferonalpha subtype responses of human plasmacytoid dendritic cells. J Interferon Cytokine Res 28 (2008) 749-63.

[23] L.M. Schramm, K.D. Kirschman, M. Heuer, A.A. Chen, D. Verthelyi, M. Puig, and R.L. Rabin, High-throughput quantitative real-time polymerase chain reaction array for absolute and relative quantification of rhesus macaque types I, II, and III interferon and their subtypes. J Interferon Cytokine Res 32 (2012) 407-15.

[24] L. Prokunina-Olsson, B. Muchmore, W. Tang, R.M. Pfeiffer, H. Park, H. Dickensheets, D. Hergott, P. Porter-Gill, A. Mumy, I. Kohaar, S. Chen, N. Brand, M. Tarway, L. Liu, F. Sheikh, J. Astemborski, H.L. Bonkovsky, B.R. Edlin, C.D. Howell, T.R. Morgan, D.L. Thomas, B. Rehermann, R.P. Donnelly, and T.R. O'Brien, A variant upstream of IFNL3 (IL28B) creating a new interferon gene 
IFNL4 is associated with impaired clearance of hepatitis C virus. Nat Genet 45 (2013) 164-71.

[25] S.V. Kotenko, G. Gallagher, V.V. Baurin, A. Lewis-Antes, M. Shen, N.K. Shah, J.A. Langer, F. Sheikh, H. Dickensheets, and R.P. Donnelly, IFN-lambdas mediate antiviral protection through a distinct class II cytokine receptor complex. Nat Immunol 4 (2003) 69-77.

[26] J. Chen, E. Baig, and E.N. Fish, Diversity and relatedness among the type I interferons. J Interferon Cytokine Res 24 (2004) 687-98.

[27] J. Kumaran, L. Wei, L.P. Kotra, and E.N. Fish, A structural basis for interferonalpha-receptor interactions. FASEB J 21 (2007) 3288-96.

[28] S. Pestka, J.A. Langer, K.C. Zoon, and C.E. Samuel, Interferons and their actions. Annu Rev Biochem 56 (1987) 727-77.

[29] P. Lamken, S. Lata, M. Gavutis, and J. Piehler, Ligand-induced assembling of the type I interferon receptor on supported lipid bilayers. J Mol Biol 341 (2004) 30318.

[30] J. Piehler, L.C. Roisman, and G. Schreiber, New structural and functional aspects of the type I interferon-receptor interaction revealed by comprehensive mutational analysis of the binding interface. J Biol Chem 275 (2000) 40425-33.

[31] L.C. Roisman, D.A. Jaitin, D.P. Baker, and G. Schreiber, Mutational analysis of the IFNAR1 binding site on IFNalpha2 reveals the architecture of a weak ligandreceptor binding-site. J Mol Biol 353 (2005) 271-81.

[32] T. Yamaoka, S. Kojima, S. Ichi, Y. Kashiwazaki, T. Koide, and Y. Sokawa, Biologic and binding activities of IFN-alpha subtypes in ACHN human renal cell carcinoma cells and Daudi Burkitt's lymphoma cells. J Interferon Cytokine Res 19 (1999) 1343-9.

[33] G.R. Foster, O. Rodrigues, F. Ghouze, E. Schulte-Frohlinde, D. Testa, M.J. Liao, G.R. Stark, L. Leadbeater, and H.C. Thomas, Different relative activities of human cell-derived interferon-alpha subtypes: IFN-alpha 8 has very high antiviral potency. J Interferon Cytokine Res 16 (1996) 1027-33.

[34] P. Palmer, M.G. Tovey, F. Raschilas, L. Brassart, J.F. Meritet, R. Porcher, and P. Lebon, Type I interferon subtypes produced by human peripheral mononuclear cells from one normal donor stimulated by viral and non-viral inducing factors. Eur Cytokine Netw 18 (2007) 108-14.

[35] S.J. Sperber, D.J. Gocke, C. Haberzettl, R. Kuk, B. Schwartz, and S. Pestka, AntiHIV-1 activity of recombinant and hybrid species of interferon-alpha. J Interferon Res 12 (1992) 363-8.

[36] T. Koyama, N. Sakamoto, Y. Tanabe, M. Nakagawa, Y. Itsui, Y. Takeda, S. Kakinuma, Y. Sekine, S. Maekawa, Y. Yanai, M. Kurimoto, and M. Watanabe, Divergent activities of interferon-alpha subtypes against intracellular hepatitis $\mathrm{C}$ virus replication. Hepatol Res 34 (2006) 41-9.

[37] S. Pestka, C.D. Krause, and M.R. Walter, Interferons, interferon-like cytokines, and their receptors. Immunol Rev 202 (2004) 8-32.

[38] C. Scagnolari, S. Trombetti, C. Selvaggi, T. Carbone, K. Monteleone, L. Spano, P. Di Marco, A. Pierangeli, F. Maggi, E. Riva, and G. Antonelli, In vitro sensitivity of human metapneumovirus to type I interferons. Viral Immunol 24 (2011) 159-64. 
[39] P.K. Weck, S. Apperson, L. May, and N. Stebbing, Comparison of the antiviral activities of various cloned human interferon-alpha subtypes in mammalian cell cultures. J Gen Virol 57 (1981) 233-7.

[40] Y. Yanai, O. Sanou, T. Kayano, H. Ariyasu, K. Yamamoto, H. Yamauchi, H. Ikegami, and M. Kurimoto, Analysis of the antiviral activities of natural IFN-alpha preparations and their subtype compositions. J Interferon Cytokine Res 21 (2001) 835-41.

[41] L. Hibbert, and G.R. Foster, Human type I interferons differ greatly in their effects on the proliferation of primary B cells. J Interferon Cytokine Res 19 (1999) 30918.

[42] C.M. Hilkens, J.F. Schlaak, and I.M. Kerr, Differential responses to IFN-alpha subtypes in human T cells and dendritic cells. J Immunol 171 (2003) 5255-63.

[43] M.S. Harper, K. Guo, K. Gibbert, E.J. Lee, S.M. Dillon, B.S. Barrett, M.D. McCarter, K.J. Hasenkrug, U. Dittmer, C.C. Wilson, and M.L. Santiago, Interferon-alpha Subtypes in an Ex Vivo Model of Acute HIV-1 Infection: Expression, Potency and Effector Mechanisms. PLoS Pathog 11 (2015) e1005254.

[44] L.A. Zaritsky, A. Dery, W.Y. Leong, L. Gama, and J.E. Clements, Tissue-specific interferon alpha subtype response to SIV infection in brain, spleen, and lung. J Interferon Cytokine Res 33 (2013) 24-33.

[45] S.L. Bixler, N.G. Sandler, D.C. Douek, and J.J. Mattapallil, Suppressed Th17 Levels Correlate with Elevated PIAS3, SHP2, and SOCS3 Expression in CD4 T cells During Acute Simian Immunodeficiency Virus Infection. J Virol (2013).

[46] M.D. Eberly, M. Kader, W. Hassan, K.A. Rogers, J. Zhou, Y.M. Mueller, M.J. Mattapallil, M. Piatak, Jr., J.D. Lifson, P.D. Katsikis, M. Roederer, F. Villinger, and J.J. Mattapallil, Increased IL-15 production is associated with higher susceptibility of memory CD4 T cells to simian immunodeficiency virus during acute infection. J Immunol 182 (2009) 1439-48.

[47] J. George, E.B. Cofano, E. Lybarger, M. Louder, B.A. Lafont, J.R. Mascola, M. Robert-Guroff, and J.J. Mattapallil, Early short-term antiretroviral therapy is associated with a reduced prevalence of CD8(+)FoxP3(+) T cells in simian immunodeficiency virus-infected controller rhesus macaques. AIDS Res Hum Retroviruses 27 (2011) 763-75.

[48] M. Kader, W.M. Hassan, M. Eberly, M. Piatak, J.D. Lifson, M. Roederer, and J.J. Mattapallil, Antiretroviral therapy prior to acute viral replication preserves CD4 T cells in the periphery but not in rectal mucosa during acute simian immunodeficiency virus infection. J Virol 82 (2008) 11467-71.

[49] M. Kader, X. Wang, M. Piatak, J. Lifson, M. Roederer, R. Veazey, and J.J. Mattapallil, Alpha4(+)beta7(hi)CD4(+) memory T cells harbor most Th-17 cells and are preferentially infected during acute SIV infection. Mucosal Immunol 2 (2009) 439-49.

[50] O.O. Onabajo, J. George, M.G. Lewis, and J.J. Mattapallil, Rhesus Macaque Lymph Node PD-1(hi)CD4(+) T Cells Express High Levels of CXCR5 and IL-21 and Display a CCR7(lo)ICOS(+)Bcl6(+) T-Follicular Helper (Tfh) Cell Phenotype. PLoS One 8 (2013) e59758.

[51] A.N. Cline, J.W. Bess, M. Piatak, Jr., and J.D. Lifson, Highly sensitive SIV plasma viral load assay: practical considerations, realistic performance expectations, and 
application to reverse engineering of vaccines for AIDS. J Med Primatol 34 (2005) 303-12.

[52] J.J. Mattapallil, D.C. Douek, B. Hill, Y. Nishimura, M. Martin, and M. Roederer, Massive infection and loss of memory CD4+ T cells in multiple tissues during acute SIV infection. Nature 434 (2005) 1093-7.

[53] C.J. Pitcher, S.I. Hagen, J.M. Walker, R. Lum, B.L. Mitchell, V.C. Maino, M.K. Axthelm, and L.J. Picker, Development and homeostasis of $\mathrm{T}$ cell memory in rhesus macaque. J Immunol 168 (2002) 29-43.

[54] L.A. Renn, T.C. Theisen, M.B. Navarro, V.P. Mane, L.M. Schramm, K.D. Kirschman, G. Fabozzi, P. Hillyer, M. Puig, D. Verthelyi, and R.L. Rabin, Highthroughput quantitative real-time RT-PCR assay for determining expression profiles of types I and III interferon subtypes. J Vis Exp (2015).

[55] T. Bruel, S. Dupuy, T. Demoulins, C. Rogez-Kreuz, J. Dutrieux, A. Corneau, A. Cosma, R. Cheynier, N. Dereuddre-Bosquet, R. Le Grand, and B. Vaslin, Plasmacytoid dendritic cell dynamics tune interferon-alfa production in SIVinfected cynomolgus macaques. PLoS Pathog 10 (2014) e1003915.

[56] E.R. Wonderlich, M. Kader, V. Wijewardana, and S.M. Barratt-Boyes, Dissecting the role of dendritic cells in simian immunodeficiency virus infection and AIDS. Immunol Res 50 (2011) 228-34.

[57] E.R. Wonderlich, W.C. Wu, D.P. Normolle, and S.M. Barratt-Boyes, Macrophages and Myeloid Dendritic Cells Lose T Cell-Stimulating Function in Simian Immunodeficiency Virus Infection Associated with Diminished IL-12 and IFNalpha Production. J Immunol 195 (2015) 3284-92.

[58] A.S. Beignon, K. McKenna, M. Skoberne, O. Manches, I. DaSilva, D.G. Kavanagh, M. Larsson, R.J. Gorelick, J.D. Lifson, and N. Bhardwaj, Endocytosis of HIV-1 activates plasmacytoid dendritic cells via Toll-like receptor-viral RNA interactions. J Clin Invest 115 (2005) 3265-75.

[59] J.N. Mandl, A.P. Barry, T.H. Vanderford, N. Kozyr, R. Chavan, S. Klucking, F.J. Barrat, R.L. Coffman, S.I. Staprans, and M.B. Feinberg, Divergent TLR7 and TLR9 signaling and type I interferon production distinguish pathogenic and nonpathogenic AIDS virus infections. Nat Med 14 (2008) 1077-87.

[60] D. Gao, J. Wu, Y.T. Wu, F. Du, C. Aroh, N. Yan, L. Sun, and Z.J. Chen, Cyclic GMP-AMP synthase is an innate immune sensor of HIV and other retroviruses. Science 341 (2013) 903-6.

[61] J.M. Brenchley, T.W. Schacker, L.E. Ruff, D.A. Price, J.H. Taylor, G.J. Beilman, P.L. Nguyen, A. Khoruts, M. Larson, A.T. Haase, and D.C. Douek, CD4+ T cell depletion during all stages of HIV disease occurs predominantly in the gastrointestinal tract. J Exp Med 200 (2004) 749-59.

[62] Q. Li, L. Duan, J.D. Estes, Z.M. Ma, T. Rourke, Y. Wang, C. Reilly, J. Carlis, C.J. Miller, and A.T. Haase, Peak SIV replication in resting memory CD4+ T cells depletes gut lamina propria CD4+ T cells. Nature 434 (2005) 1148-52.

[63] S. Mehandru, M.A. Poles, K. Tenner-Racz, A. Horowitz, A. Hurley, C. Hogan, D. Boden, P. Racz, and M. Markowitz, Primary HIV-1 infection is associated with preferential depletion of CD4+ T lymphocytes from effector sites in the gastrointestinal tract. J Exp Med 200 (2004) 761-70. 
[64] R.S. Veazey, M. DeMaria, L.V. Chalifoux, D.E. Shvetz, D.R. Pauley, H.L. Knight, M. Rosenzweig, R.P. Johnson, R.C. Desrosiers, and A.A. Lackner, Gastrointestinal tract as a major site of CD4+ T cell depletion and viral replication in SIV infection. Science 280 (1998) 427-31.

[65] T. Doyle, C. Goujon, and M.H. Malim, HIV-1 and interferons: who's interfering with whom? Nat Rev Microbiol 13 (2015) 403-13.

[66] X. Lahaye, T. Satoh, M. Gentili, S. Cerboni, C. Conrad, I. Hurbain, A. El Marjou, C. Lacabaratz, J.D. Lelievre, and N. Manel, The capsids of HIV-1 and HIV-2 determine immune detection of the viral cDNA by the innate sensor cGAS in dendritic cells. Immunity 39 (2013) 1132-42.

[67] E. Martin-Gayo, M.J. Buzon, Z. Ouyang, T. Hickman, J. Cronin, D. Pimenova, B.D. Walker, M. Lichterfeld, and X.G. Yu, Potent Cell-Intrinsic Immune Responses in Dendritic Cells Facilitate HIV-1-Specific T Cell Immunity in HIV-1 Elite Controllers. PLoS Pathog 11 (2015) e1004930.

[68] A.M. Herzner, C.A. Hagmann, M. Goldeck, S. Wolter, K. Kubler, S. Wittmann, T. Gramberg, L. Andreeva, K.P. Hopfner, C. Mertens, T. Zillinger, T. Jin, T.S. Xiao, E. Bartok, C. Coch, D. Ackermann, V. Hornung, J. Ludwig, W. Barchet, G. Hartmann, and M. Schlee, Sequence-specific activation of the DNA sensor cGAS by Y-form DNA structures as found in primary HIV-1 cDNA. Nat Immunol 16 (2015) 1025-33.

[69] K.J. Lavender, K. Gibbert, K.E. Peterson, E. Van Dis, S. Francois, T. Woods, R.J. Messer, A. Gawanbacht, J.A. Muller, J. Munch, K. Phillips, B. Race, M.S. Harper, K. Guo, E.J. Lee, M. Trilling, H. Hengel, J. Piehler, J. Verheyen, C.C. Wilson, M.L. Santiago, K.J. Hasenkrug, and U. Dittmer, Interferon Alpha SubtypeSpecific Suppression of HIV-1 Infection In Vivo. J Virol 90 (2016) 6001-13.

[70] K.N. Brown, A. Trichel, and S.M. Barratt-Boyes, Parallel loss of myeloid and plasmacytoid dendritic cells from blood and lymphoid tissue in simian AIDS. J Immunol 178 (2007) 6958-67.

[71] K.N. Brown, V. Wijewardana, X. Liu, and S.M. Barratt-Boyes, Rapid influx and death of plasmacytoid dendritic cells in lymph nodes mediate depletion in acute simian immunodeficiency virus infection. PLoS Pathog 5 (2009) e1000413.

[72] S. Kwa, S. Kannanganat, P. Nigam, M. Siddiqui, R.D. Shetty, W. Armstrong, A. Ansari, S.E. Bosinger, G. Silvestri, and R.R. Amara, Plasmacytoid dendritic cells are recruited to the colorectum and contribute to immune activation during pathogenic SIV infection in rhesus macaques. Blood 118 (2011) 2763-73.

[73] B. Malleret, B. Maneglier, I. Karlsson, P. Lebon, M. Nascimbeni, L. Perie, P. Brochard, B. Delache, J. Calvo, T. Andrieu, O. Spreux-Varoquaux, A. Hosmalin, R. Le Grand, and B. Vaslin, Primary infection with simian immunodeficiency virus: plasmacytoid dendritic cell homing to lymph nodes, type I interferon, and immune suppression. Blood 112 (2008) 4598-608.

[74] R.K. Reeves, T.I. Evans, J. Gillis, F.E. Wong, G. Kang, Q. Li, and R.P. Johnson, SIV infection induces accumulation of plasmacytoid dendritic cells in the gut mucosa. J Infect Dis 206 (2012) 1462-8.

[75] Z.D. Swan, E.R. Wonderlich, and S.M. Barratt-Boyes, Macrophage accumulation in gut mucosa differentiates AIDS from chronic SIV infection in rhesus macaques. Eur J Immunol 46 (2016) 446-54. 
[76] M. Cella, D. Jarrossay, F. Facchetti, O. Alebardi, H. Nakajima, A. Lanzavecchia, and M. Colonna, Plasmacytoid monocytes migrate to inflamed lymph nodes and produce large amounts of type I interferon. Nat Med 5 (1999) 919-23.

[77] C. Lehmann, J.M. Harper, D. Taubert, P. Hartmann, G. Fatkenheuer, N. Jung, J. van Lunzen, H.J. Stellbrink, R.C. Gallo, and F. Romerio, Increased interferon alpha expression in circulating plasmacytoid dendritic cells of HIV-1-infected patients. J Acquir Immune Defic Syndr 48 (2008) 522-30.

[78] F.P. Siegal, N. Kadowaki, M. Shodell, P.A. Fitzgerald-Bocarsly, K. Shah, S. Ho, S. Antonenko, and Y.J. Liu, The nature of the principal type 1 interferon-producing cells in human blood. Science 284 (1999) 1835-7.

[79] M. Swiecki, and M. Colonna, Unraveling the functions of plasmacytoid dendritic cells during viral infections, autoimmunity, and tolerance. Immunol Rev 234 (2010) 142-62.

[80] A.N. Theofilopoulos, R. Baccala, B. Beutler, and D.H. Kono, Type I interferons (alpha/beta) in immunity and autoimmunity. Annu Rev Immunol 23 (2005) 30736.

[81] L. Campillo-Gimenez, M. Laforge, M. Fay, A. Brussel, M.C. Cumont, V. Monceaux, O. Diop, Y. Levy, B. Hurtrel, J. Zaunders, J. Corbeil, C. Elbim, and J. Estaquier, Nonpathogenesis of simian immunodeficiency virus infection is associated with reduced inflammation and recruitment of plasmacytoid dendritic cells to lymph nodes, not to lack of an interferon type I response, during the acute phase. $J$ Virol 84 (2010) 1838-46.

[82] L.D. Harris, B. Tabb, D.L. Sodora, M. Paiardini, N.R. Klatt, D.C. Douek, G. Silvestri, M. Muller-Trutwin, I. Vasile-Pandrea, C. Apetrei, V. Hirsch, J. Lifson, J.M. Brenchley, and J.D. Estes, Downregulation of robust acute type I interferon responses distinguishes nonpathogenic simian immunodeficiency virus (SIV) infection of natural hosts from pathogenic SIV infection of rhesus macaques. $J$ Virol 84 (2010) 7886-91.

[83] B. Jacquelin, G. Petitjean, D. Kunkel, A.S. Liovat, S.P. Jochems, K.A. Rogers, M.J. Ploquin, Y. Madec, F. Barre-Sinoussi, N. Dereuddre-Bosquet, P. Lebon, R. Le Grand, F. Villinger, and M. Muller-Trutwin, Innate immune responses and rapid control of inflammation in African green monkeys treated or not with interferonalpha during primary SIVagm infection. PLoS Pathog 10 (2014) e1004241.

[84] A.C. Moore, S.L. Bixler, M.G. Lewis, D. Verthelyi, and J.J. Mattapallil, Mucosal and peripheral Lin- HLA-DR+ CD11c/123- CD13+ CD14- mononuclear cells are preferentially infected during acute simian immunodeficiency virus infection. $J$ Virol 86 (2012) 1069-78. 


\section{Figure Legends}

726 Figure 1. Reverse transcriptase inhibitors significantly suppressed plasma IFN $\alpha$

727 during acute SIV infection. (a) Kinetics of plasma viral loads (Limit of detection is 30

728 copies $/ \mathrm{ml}$ of plasma) and (b) plasma IFN $\alpha$ levels during the $1^{\text {st }} 2$ weeks of SIV infection

729 in untreated $(n=8)$ and treated $(n=4)$ animals. Treated animals received reverse

730 transcriptase inhibitors starting at day 7 post-infection. (c) Correlation between plasma

731 viral loads and plasma IFN $\alpha$ levels at day 10 pi from untreated $(n=8)$ and treated $(n=$

732 4) animals. (d) Kinetics of SIV DNA loads in CD4 memory T cells in untreated and

733 treated animals during the $1^{\text {st }} 2$ weeks of SIV infection. (e) Correlation between CD4

734 memory $T$ cell-associated SIV DNA loads and plasma IFN $\alpha$ levels at day 10 pi from

735 untreated $(n=8)$ and treated $(n=4)$ animals. Line of fit was determined using linear

736 regression analysis and correlations were derived using Spearman's rank test. Error

737 bars represent standard error and * denotes $p<0.05$.

738 Figure 2. Most Type I and III IFN subtypes are significantly upregulated in the LN

739 at day 10 post infection. Absolute copies of Type I and III IFN subtypes was

740 determined in total cells isolated from peripheral blood (PBMC), jejunum, and lymph

741 nodes (LN) at day 10 and $14-31$ post infection using a qRT-PCR assay and compared

742 to pre-infection values. Absolute copy numbers were determined using rhesus macaque

743 IFN subtype specific standards. Statistical analysis was performed using Mann-Whitney

$744 U$ test and a $p<0.05\left(^{*}\right)$ was considered significant.

745 Figure 3. Dendritic cells are the primary producers of all IFN subtypes at 10 days

746 post infection. Highly purified populations of T cells (CD4+ and CD8+),

747 monocytes/macrophages (CD14+/CD14-) and dendritic cells (DC) were sorted using a 
748 BD FACS Aria sorter and used for quantifying IFN subtype transcripts using a qRT-PCR

749 assay. Absolute copy numbers were determined using rhesus macaque IFN subtype

750 specific standards. Statistical analysis was performed using Mann-Whitney U test and a

$751 \mathrm{p}<0.05\left(^{*}\right)$ was considered significant.

752

753

754 
a)

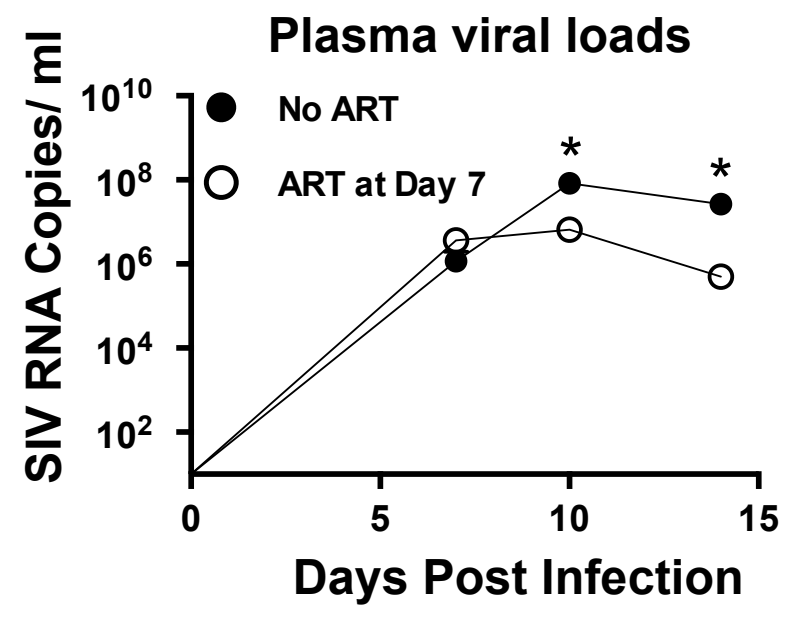

b) d)

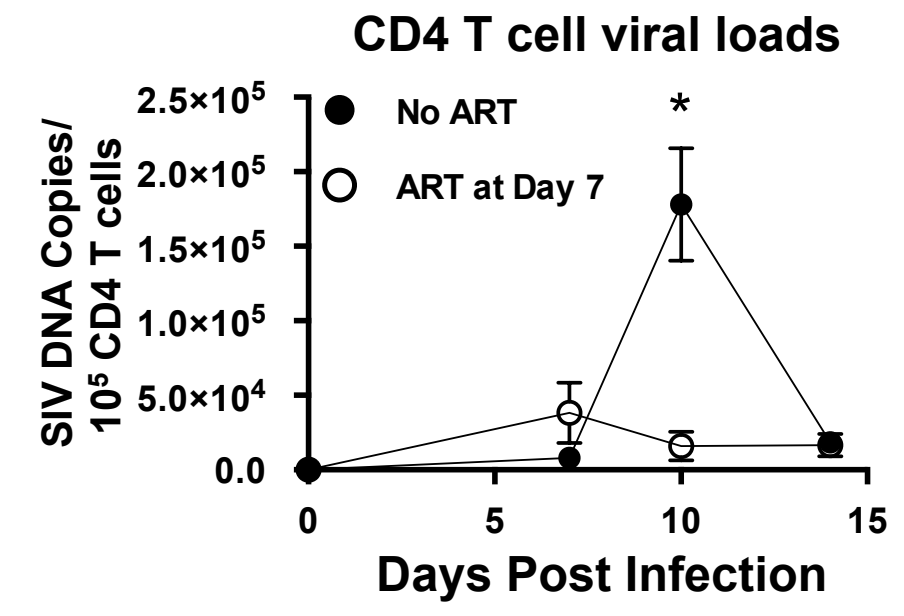

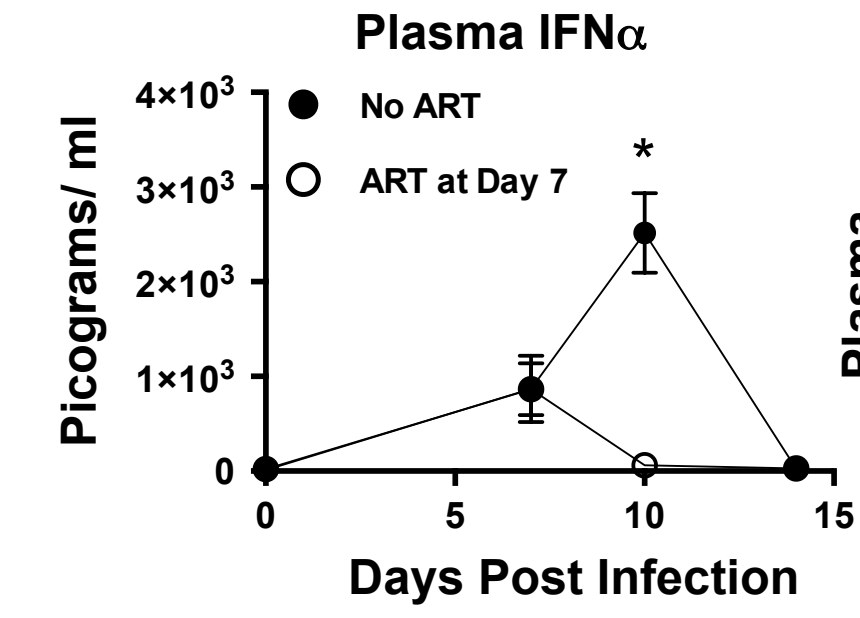

e)

c)

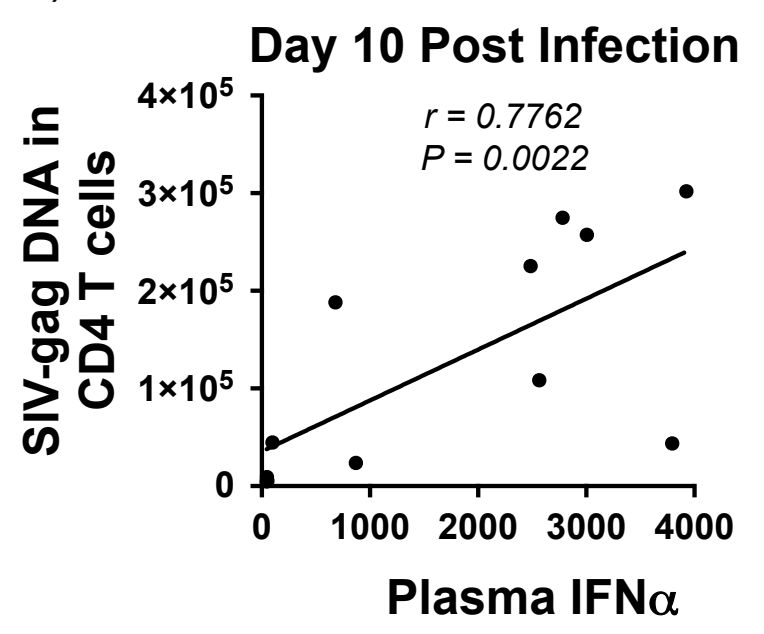

Day 10 Post Infection

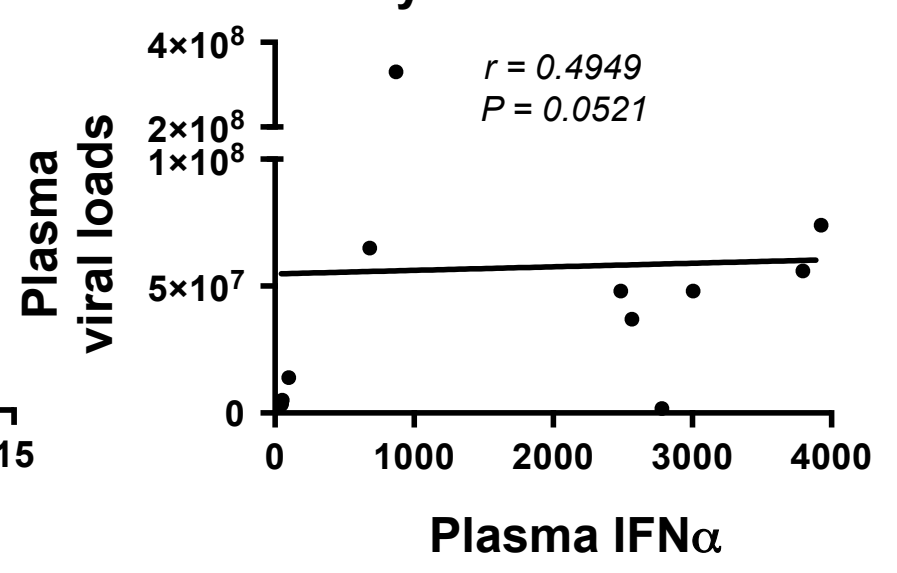

George et al Figure 1 
IFN $\alpha-01 / 13$

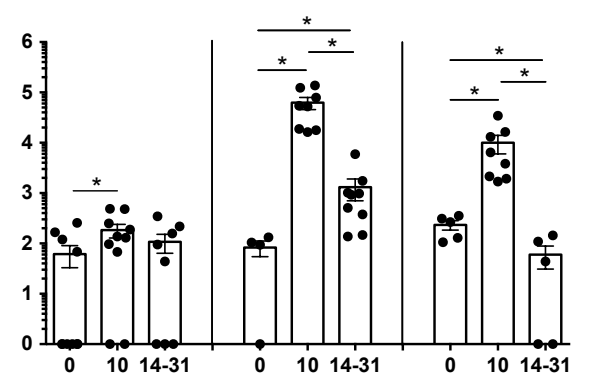

IFN $\alpha-14$
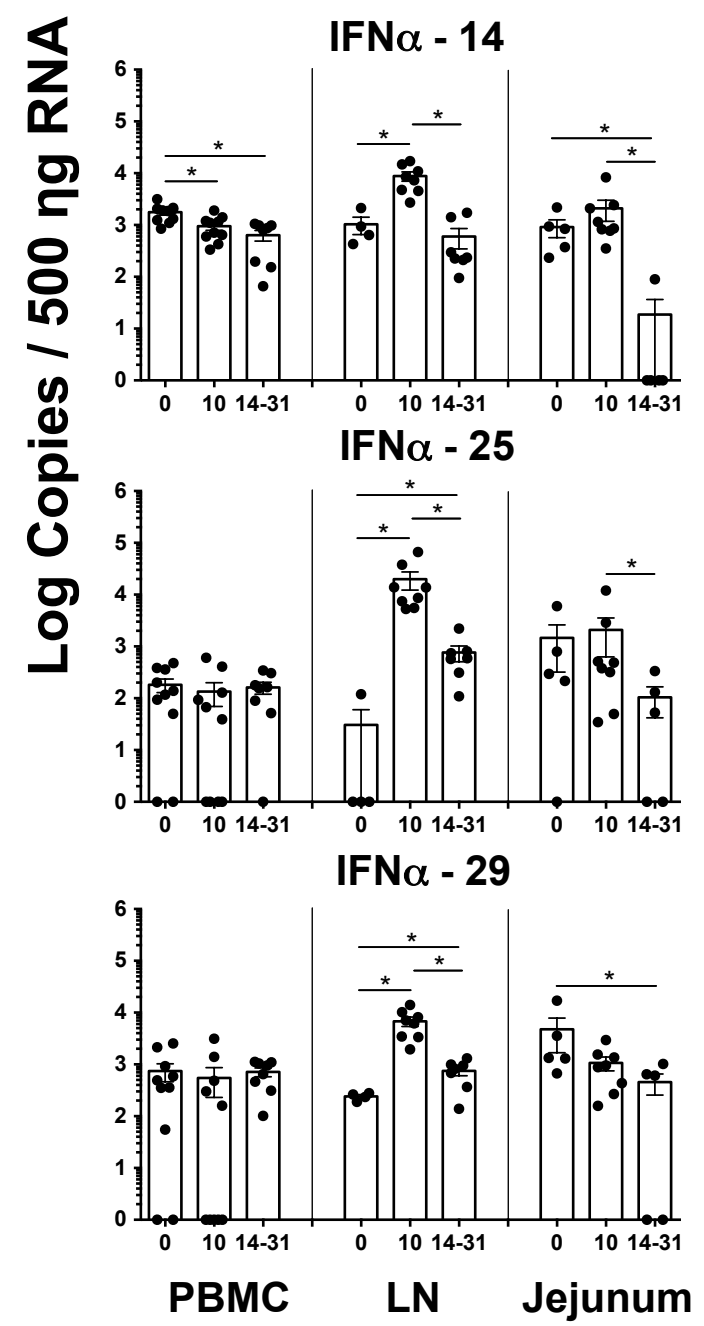

IFN $\alpha-02$

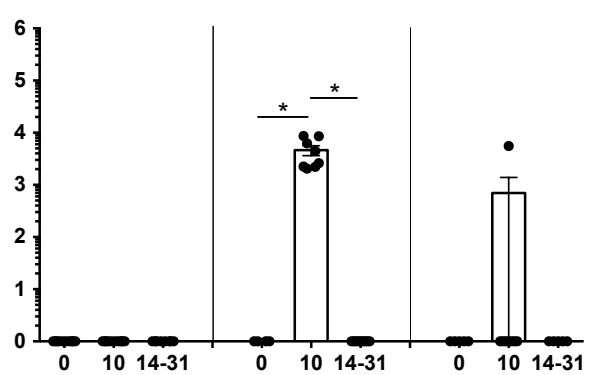

IFN $\alpha-16$
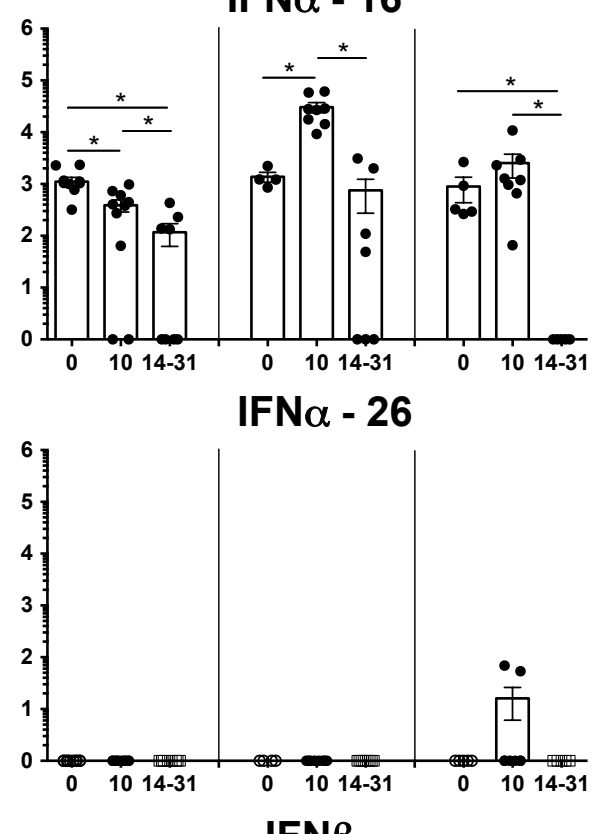

IFN $\beta$

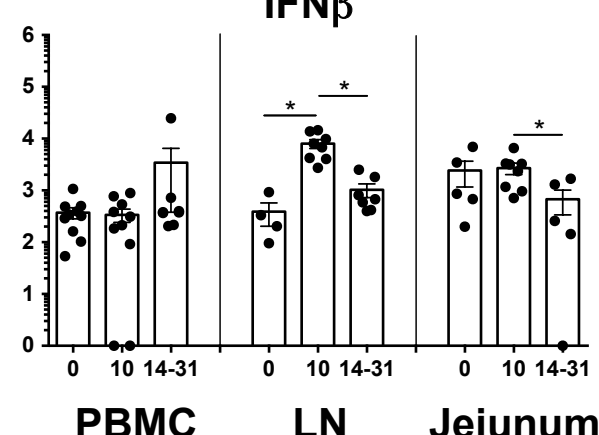

IFN $\alpha-06$

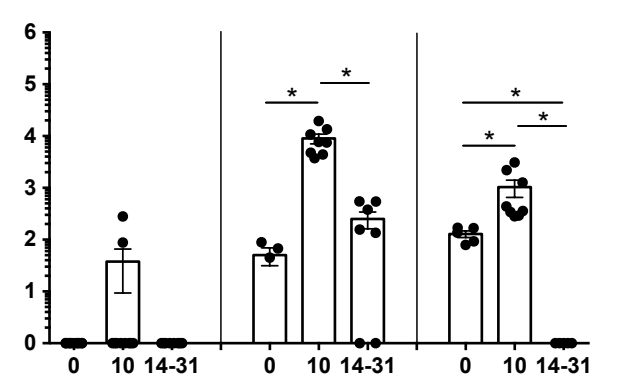

IFN $\alpha-23$

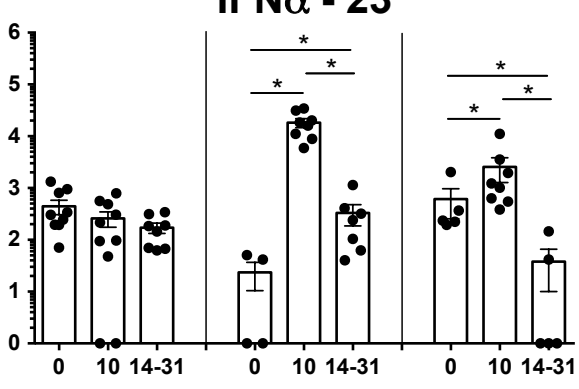

IFN $\alpha-27$

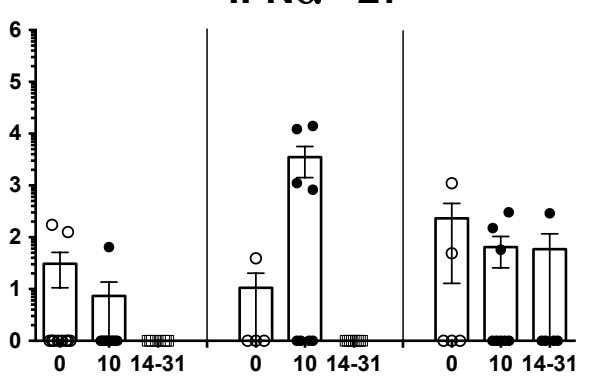

IF $\mathrm{N} \omega$

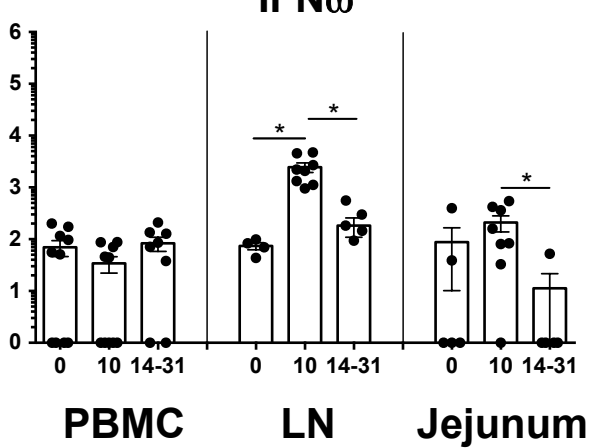

Days Post Infection
IFN $\alpha-08$

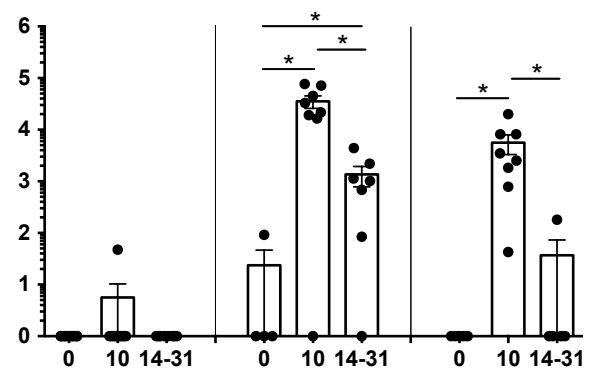

IFN $\alpha-24$

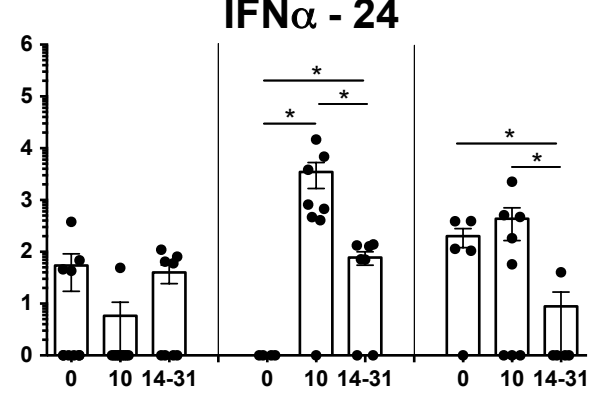

IFN $\alpha$ - 28

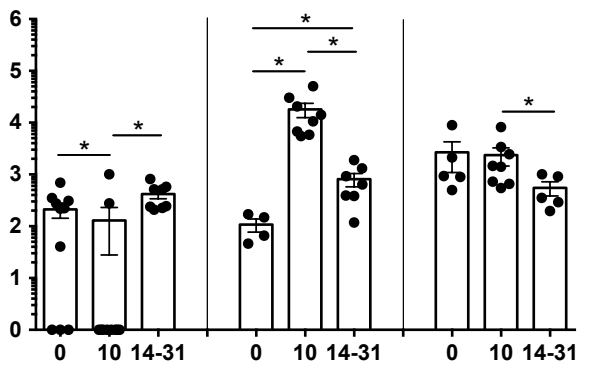

IFNA - 1

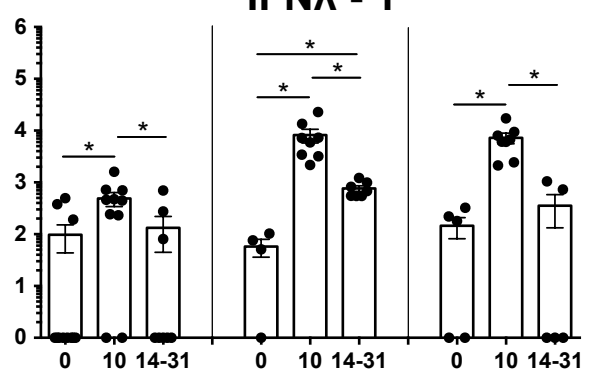

PBMC LN Jejunum

George et al Figure 2 


\section{Day 10 Post Infection}
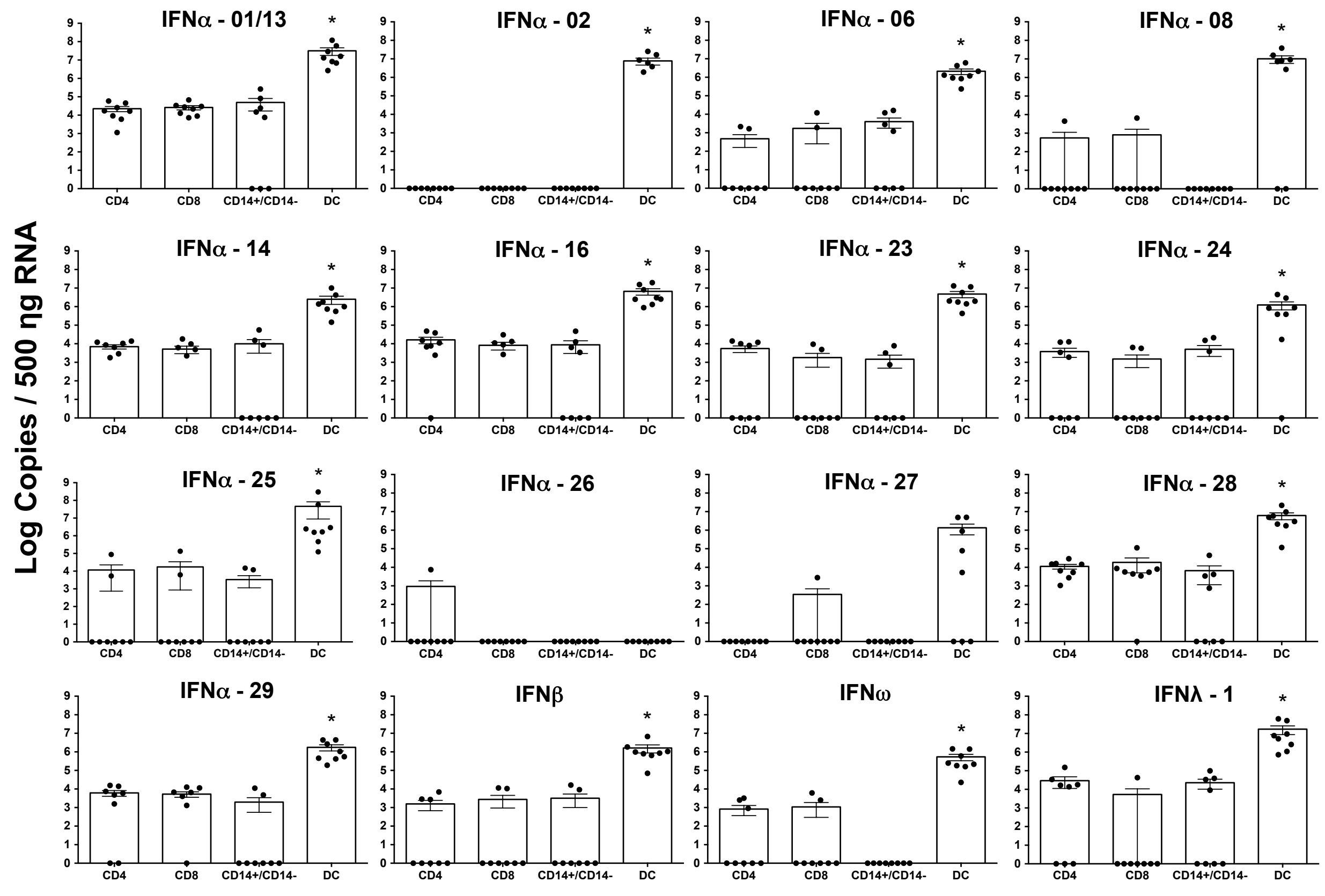

Lymph Node Cell Subsets

George et al Figure 3 